\title{
US universities oppose cap on federal funding
}

Washington. Universities across the United States are mounting a fierce campaign to kill a provision in President Bill Clinton's budget proposals for next year which, they claim, threatens to throw their finances into chaos whilst unfairly penalizing those institutions that are most successful in attracting research money.

The provision, contained in the administration's 1995 budget proposals published last month, would cap at 1994 levels the total amount of money that any university could claim from the federal government to cover the indirect costs of research.

Finance officers at large research universities are already planning multimillion dollar cuts from this summer to comply with the proposal (see below), while Washington lobbyists and well-connected university presidents are marshalling all the forces they can to kill it in Congress.

The amount of money to be held back is small, between $\$ 130$ million and $\$ 170$ million, out of the $\$ 12$ billion the federal government will pay for university research this year. But universities are terrified of the proposal.

Their main concerns are that what the budget language calls a "one-year pause" in the growth of federal support for indirect costs could become a permanent freeze, and that by reopening the issue of indirect costs, the proposal will invite hostile congressmen to focus on such costs as a way of attacking universities in general.

The universities are also angry that Clinton wrote to the president of Massachusetts Institute of Technology, Charles Vest, last spring, promising that he would not seek to cap indirect costs.

The universities may have lost valuable weeks in fighting the proposal - which they heard of only days before the budget was published - because some feared that a public fight could create a backlash. Indirect costs are soft ground for the universities to fight on, as they cover expenses ranging from lighting, heating and gardening to administrative costs, each of which Congress has been reluctant to pay for.

Last week, however, Cornelius Pings, the president of Association American Universities (AAU), sent an unusually forthright letter to John Gibbons, the president's science adviser, and Alice Rivlin, deputy director of the Office of Management and Budget, describing the proposed move as "bad science policy, bad public policy and flawed budgeting".

Pings said in the letter that the provision would impose "serious damage" on the relationship between government and universities, and warned of an "erosion of credibility, with human and financial consequences which can now only be guessed at, but which will be neither trivial nor short-term".

$\mathrm{He}$ also warned that "yours will be the first administration in fifty years to raise serious questions of dependability and trust" by setting "a rule both arbitrary and gratuitous". It would leave a "clear sense of cavalier underconcern for the impact on the universities and the nation's science programme".

IMAGE
UNAVAILABLE
FOR
COPYRIGHT
REASONS

According to Pings, the implementation of the provision would lead to "great stress and game-playing within the program agencies and on the campuses", and universities might choose to sue the government for breach of contract.

"We are not

Pings: warns of serious damage

whining about the money," he wrote. "If you really need $\$ 130$ million, just take it. But please have the forthrightness to take it by adjusting your commitment to total science support." Pings points out that the proposal will inflict the most pain on successful universities, while those whose research programmes have stagnated will be left unscathed.

The AAU says that a freeze on overhead payments would directly undermine universities which have invested money in new research laboratories. Such facilities were often cost-justified on the basis that they

would attract extra federal research funding, the indirect element of which would pay off the loan on the building. But under the proposed freeze, no additional money could be forthcoming.

The precise way in which the proposal would work has not been finalized. But as it now stands, it would require each university to add together its indirect funding from all federal sources and then ensure that the 1995 figure did not exceed that for 1994. The problem of compiling such figures may get worse when the congressional appropriations subcommittees responsible for different agencies decide how to interpret the proposal.

But some key congressional staff are sympathetic to the AAU's arguments. One who deals with funding for the largest research agency, the National Institutes of Health, says that, although the Clinton proposal in its present form has no support, his committee would be reluctant to replace it with a straight cut in research funding.

The "pause" proposal was accepted as part of the outline budget proposal passed by the House of Representatives last week. But the universities are optimistic that it will be modified as the detailed budget is hammered out in appropriations subcommittees over the summer. Their difficulty is that they are playing a zero-sum game: whatever progress they make in defending their indirect cost base will probably be at the expense of the rest of the science budget.

Colin Macilwain

\section{Los Angeles plans for the worst}

The University of Southern California (USC) has made exceptional progress in attracting federal research money in recent years. But the administrative vice-president, Dennis Dougherty, must be starting to ask if it was worth the effort.

USC is a private institution in Los Angeles, outside the public University of California system, and is one of the top 20 US research universities. In the current financial year, which ends on $\mathbf{3 0}$ June, it will attract around $\mathbf{\$ 2 1 5}$ million in federal funds, of which $\$ 52.5$ million is to cover indirect costs.

Given recent strong growth at the schools of medicine, engineering and basic sciences, Dougherty had expected the total to increase to $\mathbf{\$ 2 3 5}$ million next year, with $\mathbf{\$ 5 8}$ million for indirect costs. But he is now busy preparing for a threatened freeze on the indirect portion which, if passed by Congress, will leave the university $\mathbf{\$ 5 . 5}$ million short.

Dougherty says the result will be "a general wringing out" of costs, similar to a previous round of cuts that cost 600 support jobs at USC in 1992. This time, he says, the cuts will "change the quality of life" on his campus in south central Los Angeles.

About half of the savings will be made centrally, he says, leaving the deans at the three main research schools to find the rest. "The deans are going to have less opportunity to recruit, and the impact will roll through into salary policy," he says.

"If they want to save $\$ 150$ million they should just appropriate $\mathbf{\$ 1 5 0}$ million less,". asserts Dougherty. "What they've done is Increase it by 10 per cent, and say they're not going to pay you for light, fuel, buildings or support. The longer-term implication is that if we are going to expand aggressively, we need to be more confident that our partners in government agencies can be depended upon to pay their share." 